\title{
miRNA-1180 suppresses HCC cell activities via TRAF1/NF-kB signaling pathway
}

\author{
Feng ZHENG $^{1 *}$ iD, Zheng WANG ${ }^{1}$
}

\begin{abstract}
The miRNA-1180 anti-cancer effects in hepatocellular carcinoma cell were studied. 33 hepatocellular carcinoma patients were collected. In cancer and adjacent normal tissue from patients, TRAF1 protein and miR-1180 expression was determined by HE staining, IHC and RT-PCR methods. In the cell experiments, HepG2 cells were divided into three groups: NC group, BL group and miRNA group. The cells of NC group were un-treated; BL group were transfected with empty camer; miRNA group were transfixed with miRNA-1180. We determinates cell proliferation rate of difference groups, measuring the cell apoptosis rate and cell cycle of difference groups by flow cytometry, detected cell invasion and migration abilities of difference groups by transwell and wound healing assay and evaluating relative proteins expressions by WB assay. Compared with Normal liver tissue, cell infiltrations were significantly increased. miR-1180 was negative correlation with TRAF. The cell proliferation rate of miRNA group was significantly lower than that of NC group; The cell apoptosis and G1 phase rates were significantly difference among three groups; however, P53 and P21 protein expressions were significantly increased in miRNA groups. Over-expression miRNA-1180 had effect to inhibit HepG2 cell proliferation, invasion, migration and improve HepG2 cell apoptosis by regulation TRAF1/NF- $\kappa B$ signaling pathway.
\end{abstract}

Keywords: miRNA-1180; HepG2; TRAF1; NF-кB; P53.

Practical Application: Over-expression miRNA-1180 had effect to inhibit HepG2 cell proliferation, invasion and migration and improve HepG2 cell apoptosis by regulation TRAF1/NF- $\mathrm{kB}$ signaling pathway.

\section{Introduction}

Hepatocellular carcinoma (HCC) a kind of cancer that were higher death rate. In past few decades, the HCC treatments were significant progressing, however, the 5 year sruvival rate also remained low (Jemal et al., 2011), this was relatived with higher proliferation of HCC. microRNAs (miRNAs) were a novel class of RNA, conserved non coding sigle stranded small molecules weidely, in recent years, the miRNA was contained 22 nucleotide, the main effect of miRNA is targeted to mRNA, and degradating or inhibiting targeted mRNA translation, then suppressing the mRNA expression and regulating targeted $m R N A$ expression and somatic development, apoptosis, proliferation and differentiation (Volk \& Shomron, 2011; Jebbawi et al., 2014; Huang et al., 2014; Chiang et al., 2015). Previou relatived studies were shown that miRNA-1180 had effects to suppressing proliferation (Ge et al., 2017; Zhou et al., 2016; Tan et al., 2016). However, there were limited studies to research about relationship between miRNA-1180 and HCC. In this study, we wanted to prove the effects of miRNA-1180 to HCC and explain the mechanism.

\section{Materials and methods}

\subsection{Clinical data}

Collecting the 33 patients, who were Hepatocellular carcinoma patients and treated in our hospital. Taking the cancer and adjacent normal tissues from 33 patients, the tissues were divided into two parts: on part was fixed with formalin solution until IHC or HE staining; another part was stored in $-80^{\circ} \mathrm{C}$ refrigerator.

\subsection{Materials}

HepG2 was purchased from ATCC, DMEM and Fetal Bovine Serum were also purchased from HyClone; miRNA-1180 (Kingsy, China); Lipofectamine ${ }^{\mathrm{TM}}$ RNAiMAX (Invitrogen, USA); Opti-MEM (Gibco, USA); Cell proliferation assay kit (Promega, USA); Cell apoptosis and cycle assay kit (KeyGEN, USA); TRAF1, NF- $\kappa b$, P53, P21, MMP-2 and MMP-9 anti-body (Abcam, USA).

\subsection{Methods}

Immunohistochemistry (IHC)

The samples were fixed by $10 \%$ neutral formaldehyde and embedded in paraffin. Mouse anti human TRAF1 monoclonal antibody (R \& D). Two anti SuperPictureTM two step method was used for the detection of TRAF1, and the staining was performed by using $(\mathrm{DAB})$ staining. The antigen of $0.01 \mathrm{~mol} / \mathrm{L}$ sodium citrate $(\mathrm{pH} 6)$ was used to repair the antigen by immunohistochemistry. The remaining steps refer to the reagent instructions.

\section{$R T-P C R$}

The total RNA of differrence tissues were extracted by TRIzol total RNA kit, Checking the OD260 ultraviolet spectrophotometer, and the ratio of OD280, to determine the concentration and purity of RNA; another hybrid 3uLRNA and 2uL loading Buffer by agarose gel electrophoresis, RNA has no observed degradation; adding cDNA reverse transcriptase catalytic synthesis, fluorescence quantitative PCR with SYBR qPCR Mix. 
Primer sequence:GAPDH-F:5'AACGGATTTGGTCGTATTGGG-3'; GAPDH-R:5'-TCGCTCCTGGAAGATGGTGAT-3'. TRAF1F:5' -TCCCGTAACACCTGATTAA-3'; TRAF1-R:5'ACAACTCCCAAACCATACAC-3'. Amplification condition: $94{ }^{\circ} \mathrm{C} 30 \mathrm{~s}, 53^{\circ} \mathrm{C} 45 \mathrm{~s}, 72^{\circ} \mathrm{C} 30$ s, 40 cycles, $72{ }^{\circ} \mathrm{C} 1 \mathrm{~min}$.

\section{Cell culture and transfection}

The cells were cultured by DMEM contained 10\% FBS in $37^{\circ} \mathrm{C}, 5 \% \mathrm{CO}_{2}$ saturated humidity condition, transferring liquid once per 1 2d. The HepG2 cells inoculated with 96 hole plates were stayed in incubator, $37^{\circ} \mathrm{C}, 5 \% \mathrm{CO}_{2}$ saturated humidity condition, until transfection. The cell fusion rate was 30\% $50 \%$. The cell was started to transfecte miRNA-1180 following by Lipofectamine ${ }^{\mathrm{TM}}$ RNAiMAX instruction.

\section{MTT assay}

Inoculating the HepG2 cells into 96 hole plates as $0.5 \times 10^{4} \sim 1.0 \times 10^{4}$ cell per well, the cell were divided into 3 group: Normal Control group (NC), Blank Control group (BL) and miRNA-1180 transfection group (miRNA). The cells of NC were treated with nothing; the cells of BL were transfected with empty carrier; the cells of miRNA were transfected with miRNA-1180. After transfection, measuring the proliferation at $48 \mathrm{~h}$. Adding $10 \mu \mathrm{L}$ MTT ( $5 \mathrm{mg} / \mathrm{mL})$ into every hole, after incubating $4 \mathrm{~h}$ in cell incubator, carefully discard supernatant and add DMSO to dissolve purple crystal. The absorbance was measured at $490 \mathrm{~nm}$ with an enzyme analyzer.

\section{Cell apoptosis assay}

After transfection $48 \mathrm{~h}$, Collecting the cell from every groups, Washing the cell by PBS for twice, fixed the cell by $70 \%$ ETOH overnight. Adding corresponding reagent depend on kit's instructions, placed in avoid light for $30 \mathrm{~min}$ at $4{ }^{\circ} \mathrm{C}$, after that, measuring cell apoptosis of every groups by flow cytometry.

\section{Cell cycle assay}

After transfection $48 \mathrm{~h}$, Collecting the cell from every groups, Washing the cell by PBS for once, adding $100 \mu \mathrm{L}$ Rnase A in every tubes in $37^{\circ} \mathrm{C}$ water bath for $30 \mathrm{~min}$, and adding $400 \mu \mathrm{LPI}$, mixing them and stayed in avoid light romm at $4{ }^{\circ} \mathrm{C}$ for $30 \mathrm{~min}$. We measured cell cycle of every group by flow cytometry.

\section{Transwell assay}

After transfection, the cells were collected and cultured in serum-free medium with DMEM. The single cell suspension $\left(1 \times 10^{6}\right)$ was added to the upper chamber of the Transwell cell, and $600 \mu \mathrm{L}$ medium was added in the lower chamber. The cells of difference groups were incubated for $48 \mathrm{~h}$ at $37^{\circ} \mathrm{C}$ and contained $5 \% \mathrm{CO}_{2}$. Remove the chamber, $4 \%$ paraformaldehyde fixed 15 min, crystal violet staining of min, to detect whether the cell through the small hole, if the cell through, then immediately stop all the experimental group, take pictures and statistics.

\section{Wound healing assay}

HepG2 cells were transfected in 6 well plates in $24 \mathrm{~h}$ culture, when cell density reached $80 \% \sim 90 \%$, with a gun head than a ruler, underline the vertical force, washing the cells with PBS after 3 times, adding serum-free DMEM culture medium, respectively in $0 \mathrm{~h}$, $48 \mathrm{~h}$ camera, repeat 3 holes, the experiment was repeated 3 times.

\section{WB assay}

The cells of difference groups were washed by PBS, after centrifugation, the supernatant was discarded, adding cell lysis and protease inhibitors, fully clevaed cell on ice for $30 \mathrm{~min}$. After centrifugation, we took supernatant to new EP tube. BCA protein quantitative kit was used to determine the total protein concentration of each cell, SDSPAGE, $180 \mathrm{~mA}$ constant flow transfer protein to cellulose acetate membrane, after 5\% skimmed milk powder closed, Adding I anti-body, Incubating on the table at $4{ }^{\circ} \mathrm{C}$ overnight, Closed liquid washing 3 times were added HRP labeled II resistance, Room temperature incubation for $1 \mathrm{~h}$, luminous agent after darkroom exposure, by developing and fixing after treatment, GAPDH was used as internal reference. Image software was used to analyze the gray value of each protein zone, and the gray value of each cell and the gray value of GAPDH protein corresponding zone were compared and analyzed.

\subsection{Statistical analysis}

We used ANOVA analysis to evaluate the impact of patients' survival and clinical covanates. The factors, were significantly differences in the ANOVA analysis, were invastigated the independent effects of these variables in next step. $P<0.05$ was considered to indicate a significant statistical difference.

\section{Results}

\subsection{Clinical data analysising}

Compared with adjacent tissue, the cell invasion ability was enhanced in the cancer tissue (Figure 1A). Meanwhile, the TRAF1 protein expression was positive in the cancer tissue, and was negative in the adjacent tissue (Figure 1B). Compared with adjacent tissue, the miR-1180 expression of cancer tissue was significantly decreased $(\mathrm{P}<0.05$, Figure $1 \mathrm{C})$. Measuring the TRAF1 gene expression and analysising the correlation between TRAF1 and miR-1180. The result was shown that TRAF1 was negative correlation with miR-1180 $(r=-1.9902$, Figure 1D).

\subsection{Cell proliferation}

Compared with $\mathrm{NC}$ group, the cell proliferation rate of miRNA group was significantly decreased $(P<0.05)$; however, there were no significanly difference between $\mathrm{NC}$ and BL groups $(P>0.05)$. The data was shown in Figure 2.

\subsection{Cell apoptosis}

The cell apoptosis rate of miRNA group was significantly up-regulation compared with NC group $(P<0.05)$, and there were no significantly difference in NC and BL groups $(P>0.05)$. The data was shown in Figure 3. 
A

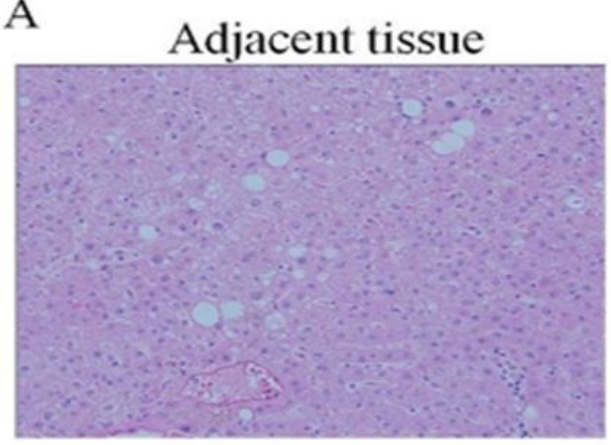

B

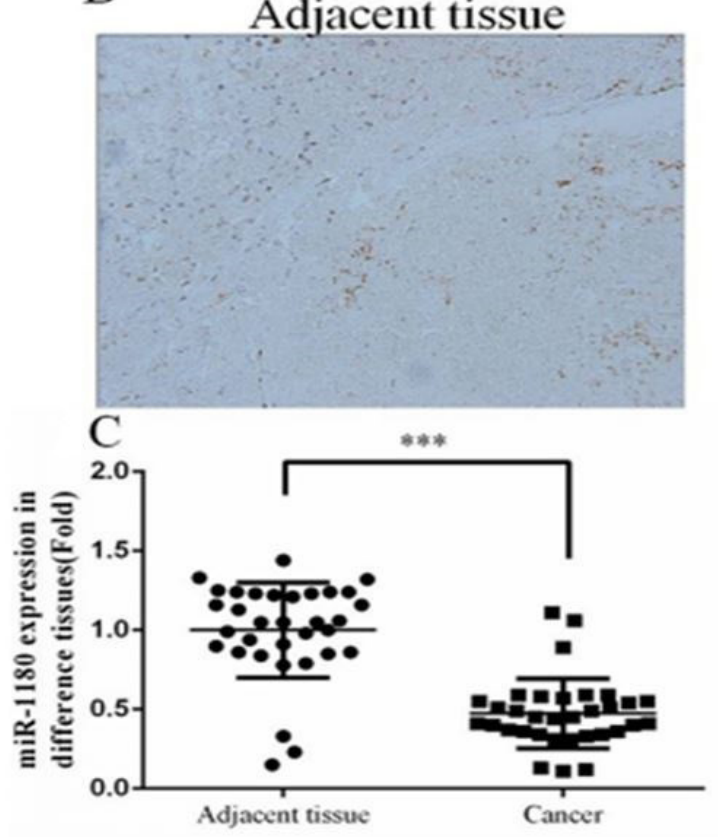



\section{Cancer}



D

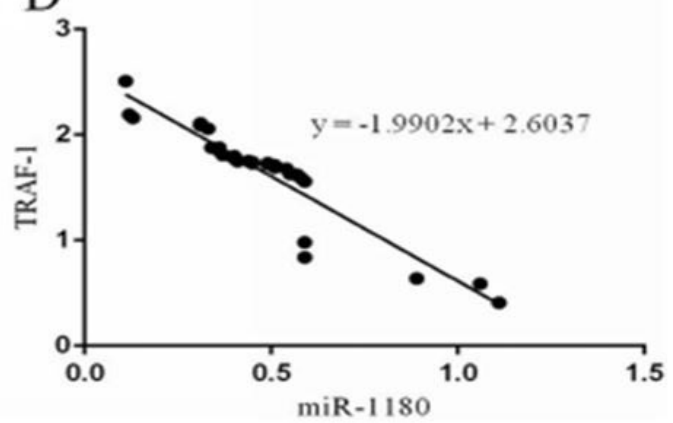

Figure 1. Clinical data. (A) Difference tissues by HE staining $(\times 200)$; (B) The TRAF1 protein expression by IHC in difference tissues $(\times 200)$; (C) The miR-1180 expression by RT-PCR. ${ }^{* *} P<0.05$, compared with adjacent tissue; (D) Correlation between TRAF1 and miR-1180. The TRAF1 was negative correlation with miR-1180 $(r=-1.9902)$.
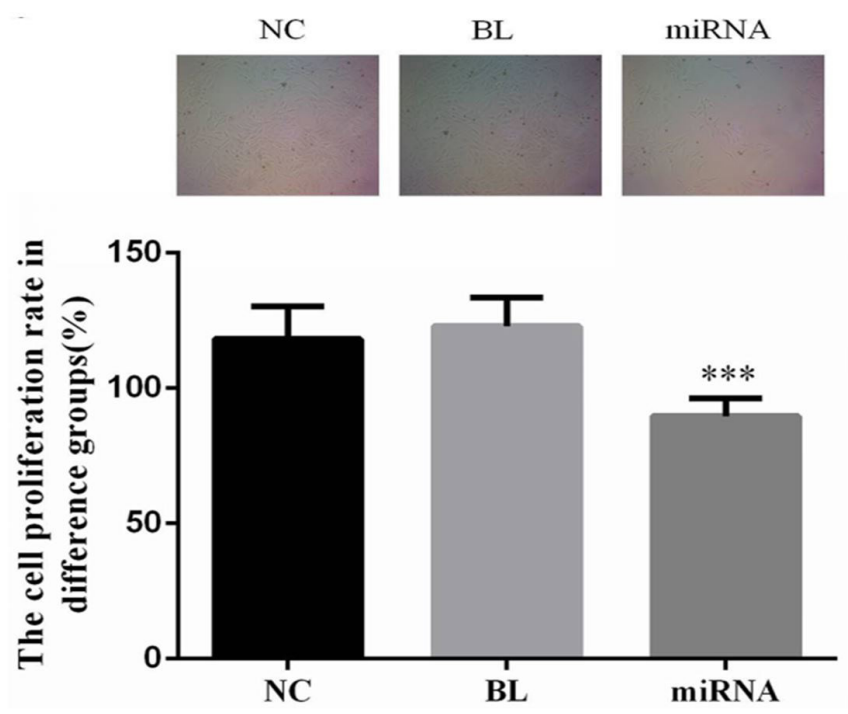

Figure 2. The cell proliferation rate in difference groups. ${ }^{* *} P<0.05$, compared with NC group.

\subsection{Cell cycle}

The G1 phase of miRNA group was significantly increase compared with $\mathrm{NC}$ group $(P<0.05)$, and there were no significantly difference in $\mathrm{NC}$ and $\mathrm{BL}$ groups $(P>0.05)$. The data was shown in Figure 4.

\subsection{Transwell assay}

Compared with NC group, the invasion cell number of miRNA group was significantly down-regulation $(P<0.05)$; however, there were no significantly difference in $\mathrm{NC}$ and $\mathrm{BL}$ groups $(P>0.05)$. The data was shown in Figure 5.

\subsection{Wound healing assay}

The wound healing rate of miRNA group was significantly reduced compared with NC group $(P<0.05)$; however, there were no significantly difference in NC and BL groups $(P>0.05)$. The data was shown in Figure 6. 
$\mathrm{NC}$

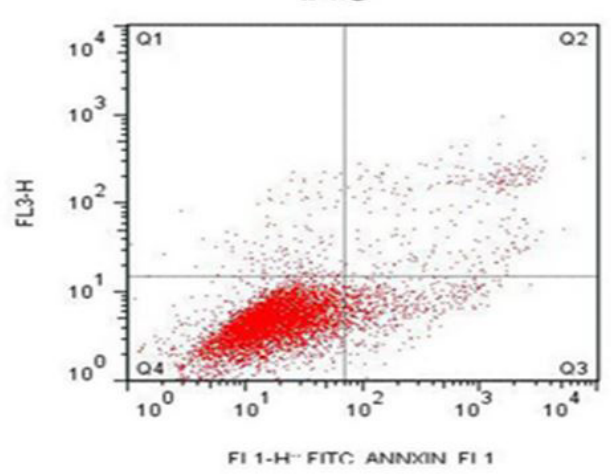

miRNA

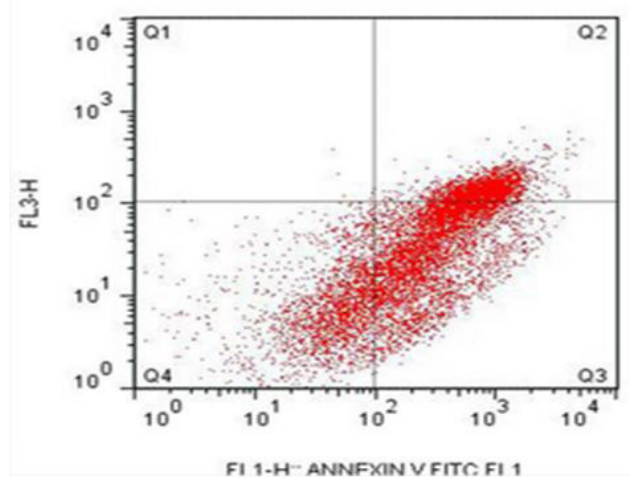

BL

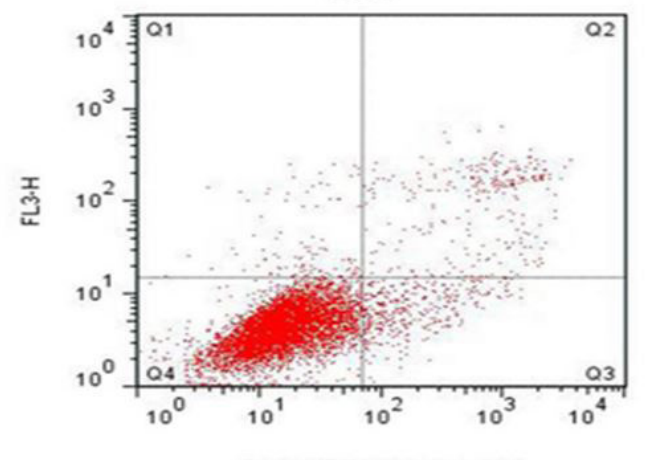

FI 1-H-FITS ANNXIN FI 1

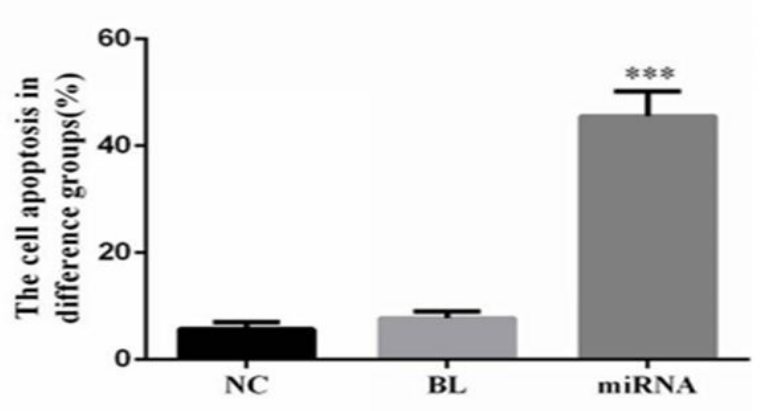

Figure 3. The cell apoptosis rate in difference groups. X-axis: FL1-H, which represents the height of cells stained by dye A-V; Y-axis: FL3-H, which represents the height of cells stained by PI. Q1, Q2, Q3 and Q 4 represent quadrant 1, 2, 3, and 4, respectively. ${ }^{* *} P<0.05$, compared with NC group.
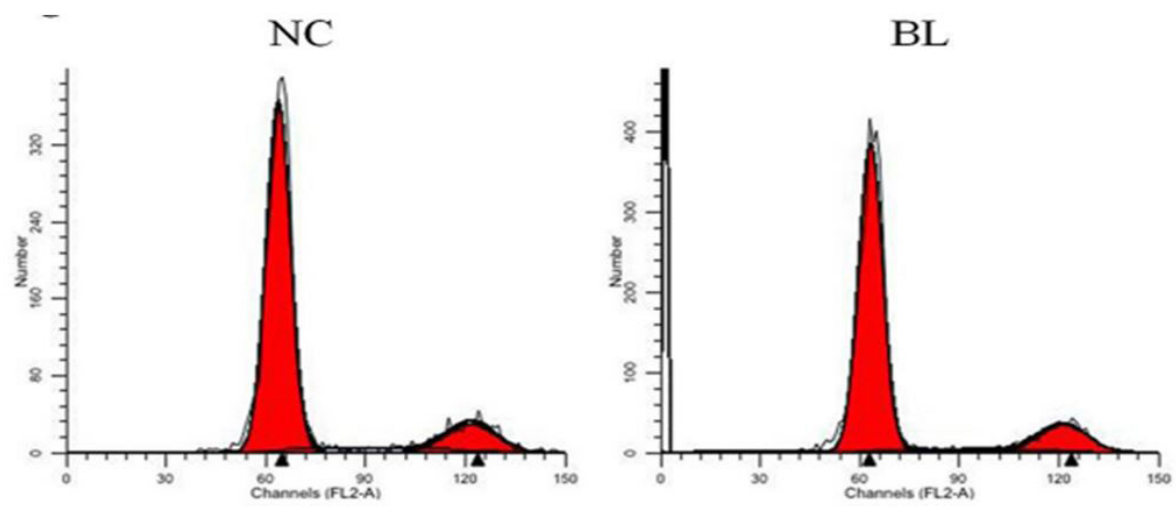

\section{MiRNA}
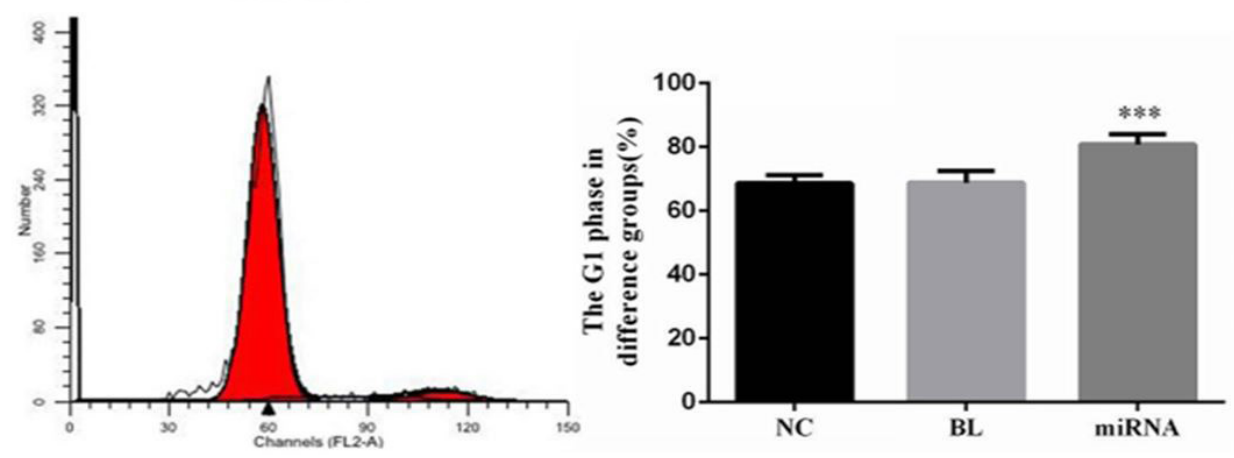

Figure 4. The cell cycle in difference groups. FL2-A is the area under the curve of the number of fluorescent channels. ${ }^{* *} P<0.05$, compared with NC group. 

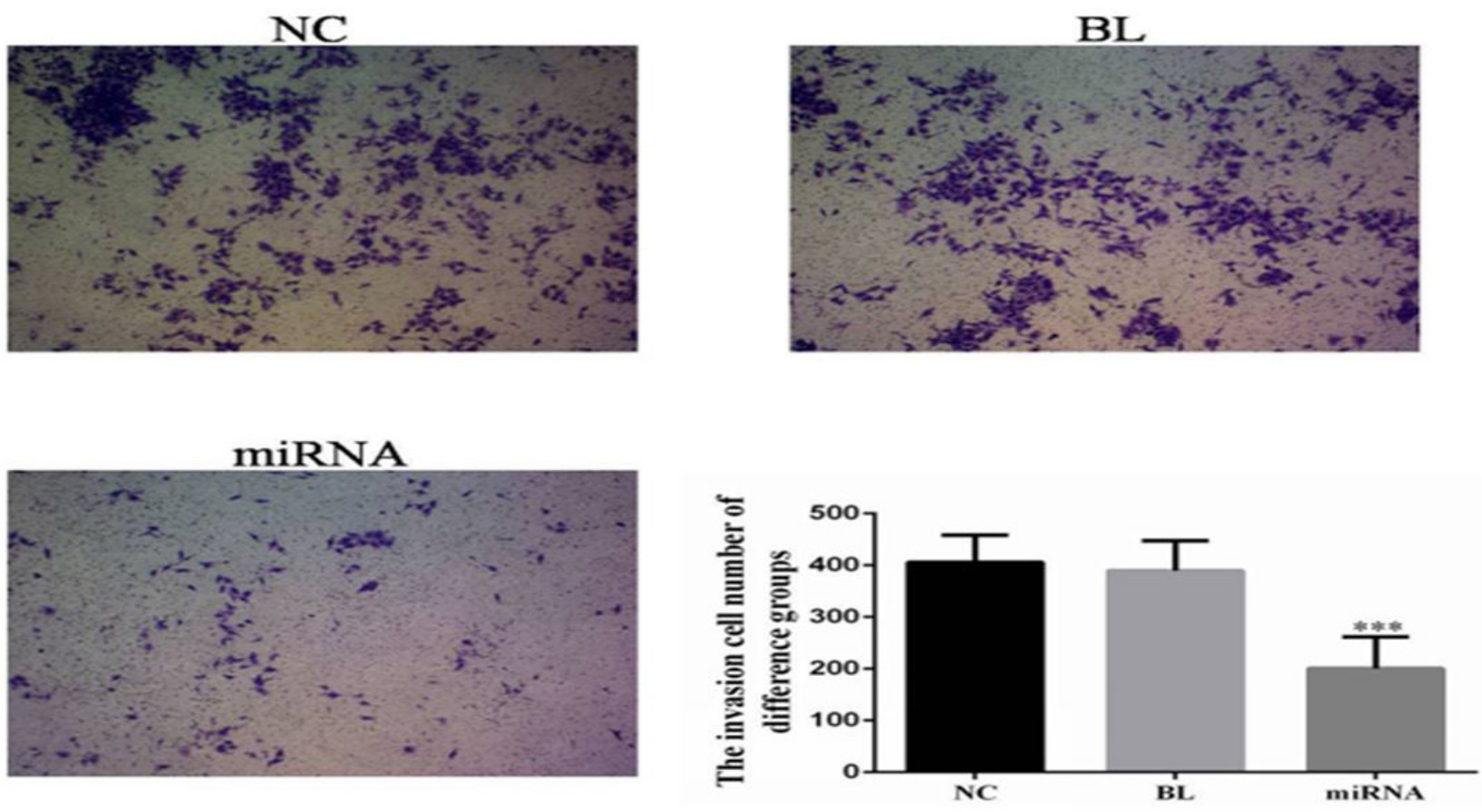

Figure 5. The invasion cell number of difference groups by transwell assay. ${ }^{\star * *} P<0.05$, compared with NC group.
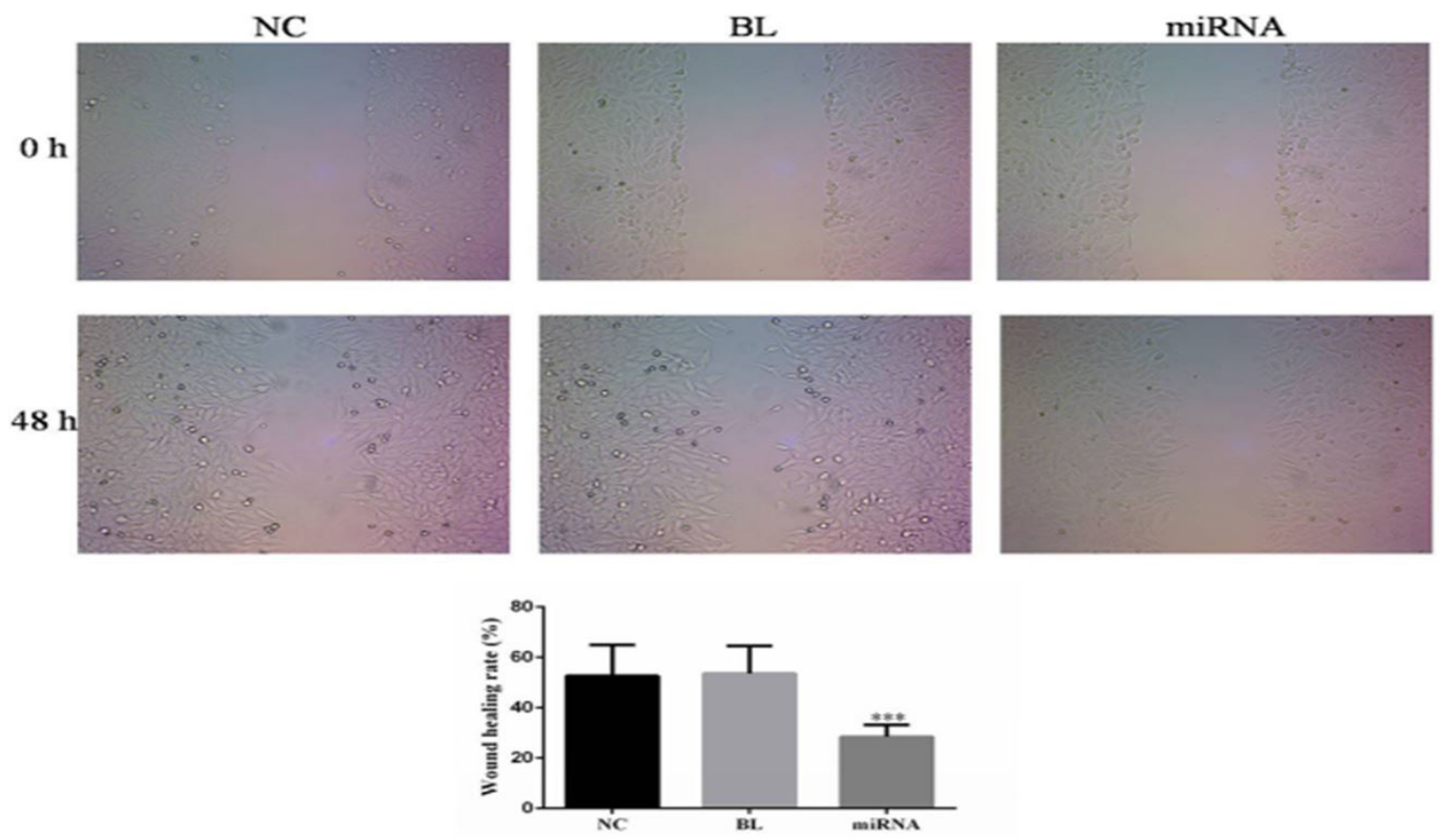

Figure 6. The wound healing rate of difference groups by wound healing assay. ${ }^{* *} P<0.05$, compared with NC group.

\subsection{WB assay}

The TRAF1, NF-кB, P53, P21, MMP-2 and MMP-9 protein expressions were significantly differences between miRNA and NC groups $(P<0.05$, respectively), however, there were no significantly differences between NC and BL groups $(P>0.05$, respectively). The data was shown in Figure 7.

\section{Discussion}

HCC is high degree of malignancy and poor prognosis, even with treatment of surgery combined with chemotherapy, the treatment effect is still poor, postoperative HCC high recurrence rate and metastasis is a key factor affecting the treatment effect and prognosis, there is an urgent need for new 

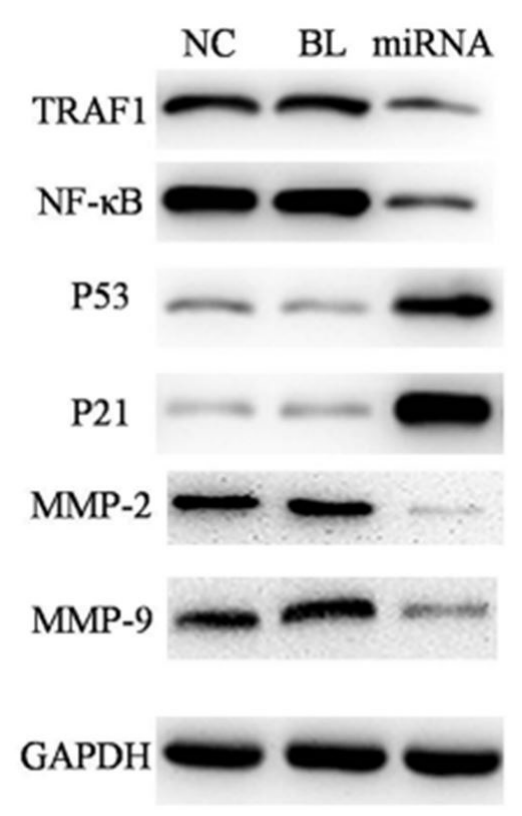
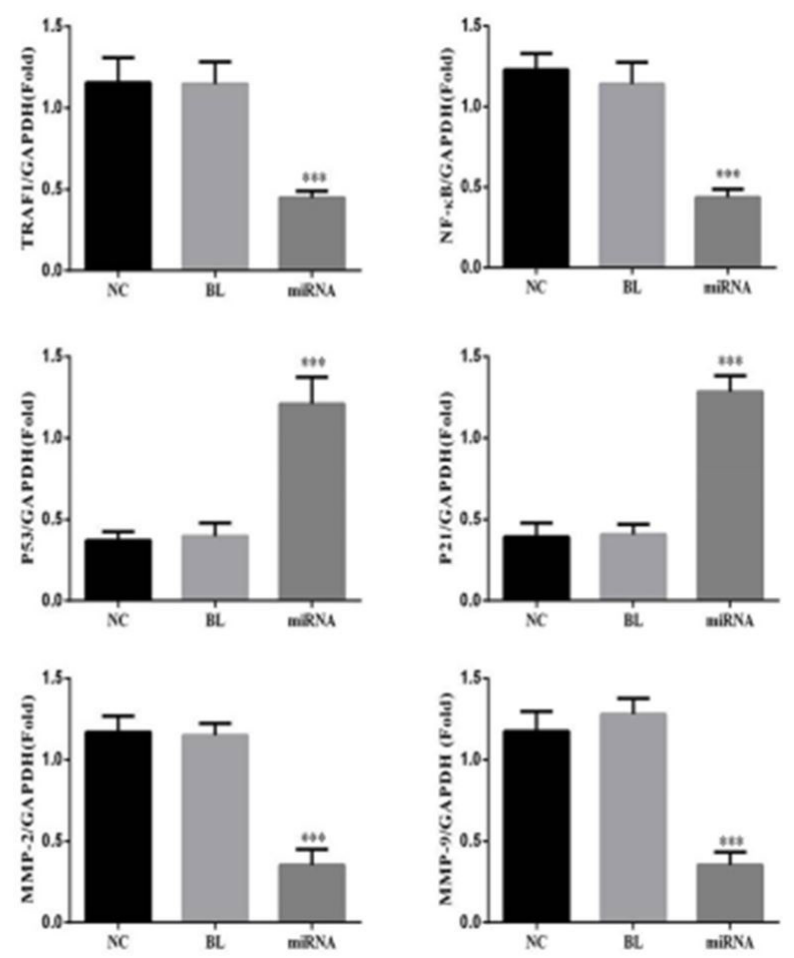

Figure 7. The relative protein expression in difference groups. ${ }^{* \star} P<0.05$, compared with NC group.

and effective therapeutic targets. miRNA has a wide range of gene regulatory functions, can regulate various aspects of gene activity, participate in a series of biological processes such as embryonic development, cell proliferation, apoptosis and energy metabolism (Esquela-Kerscher \& Slack, 2006). Some scholars had confirmed that miRNA played a role of oncogenes or tumor suppressor genes in the occurrence and development of HCC (Zhang et al., 2016; Wu et al., 2017; Yang et al., 2016); the biological behavior of HCC was closely related to some members of miRNA family (Xu et al., 2014). In this study, we firstly evaluated the TRAF1 expressions in the HCC tissues, measured the miR-1180 expression and analysis the correlation. The results were shown there were negative correlation between miR-1180 and TRAF1. This result was prompted that miR-1180 overexpression had effects to suppress the TRAF1 expreessions in HCC. The study also found that overexpression of miR-1180 significantly inhibited the proliferation of HepG2 hepatoma cells, and promote apoptosis, the cell cycle analysis showed that overexpression of miR-1180 was a large number of cells stayed in G1 phase; this result was likely to cause increased apoptosis.

Tumor necrosis factor receptor associated factor 1 (TRAF1) is a kind of adaptor protein in cytoplasm (Tokunaga et al., 2012). TRAF1 plays an important role in NF- kappa B, MAPKS and other signaling pathways, and participates in inflammation, immunity, cell proliferation and differentiation through these pathways (Kim et al., 2016; Zhang et al., 2015; Greenfeld et al., 2015). Nuclear factor-kappa B (NF- $\kappa B$ ) is an important transcription factor protein, which shows increased activity in most tumor cells. A variety of carcinogenic factors can promote cell growth by activating NF-KB pathway, leading to malignant transformation of cells and promoting metastasis of tumor cells
(Liu et al., 2016a, b). Inhibition of NF-KB activity could inhibit tumor cell proliferation, promote apoptosis, increase the sensitivity of anti-tumor cells to chemotherapy, inhibit inflammation, and reduce tumor angiogenesis (Berrak et al., 2016; Etemadi et al., 2015; Shang et al., 2015). P53, P21 genes are negative regulator of cell growth cycle, and cell cycle regulation, DNA repair, cell differentiation, cell apoptosis and other important biological functions (Lei et al., 2017; Lewinska et al., 2017; Al-Saran et al., 2016; Hrgovic et al., 2016). In this study, The P53 and P21 proteins of miRNA group was significantly up-regulation compared with NC group, this might the reason that a large number of miRNA group cells were stayed in the G1 phase to death.

The migration and invasion of tumor cells are closely related to epithelial mesenchymal transition (EMT) in the process of tumor progression (Tsai \& Yang, 2013; Yao et al., 2011). Activation of TRAF1/NF- $\kappa B$ signaling pathway plays a critical role in the induction of EMT in tumor cells (Li et al., 2017), and promote the migration and invasion of the expression of matrix metalloproteinase MMPs, thereby enhancing the migration and invasion of tumor cells (Bidard et al., 2008). In our present study, we found that the MMP-2 and MMP-9 protein expressions of miRNA-1180 overexpression group were significantly down-regulation, that might the results of HepG2 cells invasion and migration abilities suppressing.

\section{Conclusion}

In our study, we found that miRNA-1180 overexpression had effects to suppress TRAF1, NF- $\kappa B$ (downstream gene of TRAF1), MMP-2 and MMP-9 protein expressions, and stimulate P53 and P21 proteins expressions. Since the 
P53 and P21 over-expressions, a large number of HepG2 cells were stayed in the G1 phase, and suppressing MMP-2 and MMP-9 leaded the cell invasion and migration abilities in vitro experiments. Depending on those results, we inferred that miRNA-1180 might have anti-tumor effects to HepG2 cells' biological activities via TRAF1/NF- $\mathrm{KB}$ signaling pathway.

\section{References}

Al-Saran, N., Subash-Babu, P., Al-Nouri, D. M., Alfawaz, H. A., \& Alshatwi, A. A. (2016). Zinc enhances CDKN2A, pRb1 expression and regulates functional apoptosis via upregulation of p53 and p21 expression in human breast cancer MCF-7 cell. Environmental Toxicology and Pharmacology, 47, 19-27. http://dx.doi.org/10.1016/j. etap.2016.08.002. PMid:27567443.

Berrak, O., Akkoc, Y., Arisan, E. D., Çoker-Gürkan, A., ObakanYerlikaya, P., \& Palavan-Ünsal, N. (2016). The inhibition of PI3K and NFKB promoted curcumin-induced cell cycle arrest at G2/M via altering polyamine metabolism in $\mathrm{Bcl}-2$ overexpressing MCF-7 breast cancer cells. Biomedicine and Pharmacotherapy, 77, 150-160. http://dx.doi.org/10.1016/j.biopha.2015.12.007. PMid:26796279.

Bidard, F. C., Pierga, J. Y., Vincent-Salomon, A., \& Poupon, M. F. (2008). A "class action" against the microenvironment: do cancer cells cooperate in metastasis. Cancer and Metastasis Reviews, 27(1), 5-10. http://dx.doi.org/10.1007/s10555-007-9103-x. PMid:18066649.

Chiang, K., Shu, J., Zempleni, J., \& Cui, J. (2015). Dietary MicroRNA Database (DMD): an archive database and analytic tool for food-borne microRNAs. PLoS One, 10(6), e0128089. http://dx.doi.org/10.1371/ journal.pone.0128089. PMid:26030752.

Esquela-Kerscher, A., \& Slack, F. J. (2006). Oncomirs-microRNAs with a role in cancer. Nature Reviews. Cancer, 6(4), 259-269. http://dx.doi. org/10.1038/nrc1840. PMid:16557279.

Etemadi, N., Chopin, M., Anderton, H., Tanzer, M. C., Rickard, J. A., Abeysekera, W., Hall, C., Spall, S. K., Wang, B., Xiong, Y., Hla, T., Pitson, S. M., Bonder, C. S., Wong, W. W., Ernst, M., Smyth, G. K., Vaux, D. L., Nutt, S. L., Nachbur, U., \& Silke, J. (2015). TRAF2 regulates TNF and NF- $\kappa$ B signalling to suppress apoptosis and skin inflammation independently of Sphingosine kinase. eLife, 4, e10592. http://dx.doi.org/10.7554/eLife.10592. PMid:26701909.

Ge, Q., Wang, C., Chen, Z., Li, F., Hu, J., \& Ye, Z. (2017). The suppressive effects of miR-1180-5p on the proliferation and tumorigenicity of bladder cancer cells. Histology and Histopathology, 32(1), 77-86. PMid:27112784.

Greenfeld, H., Takasaki, K., Walsh, M. J., Ersing, I., Bernhardt, K., Ma, Y., Fu, B., Ashbaugh, C. W., Cabo, J., Mollo, S. B., Zhou, H., Li, S., \& Gewurz, B. E. (2015). TRAF1 coordinates polyubiquitin signaling to enhance Epstein-Barr virus LMP1-mediated growth and survival pathway activation. PLoS Pathogens, 11(5), e1004890. http://dx.doi. org/10.1371/journal.ppat.1004890. PMid:25996949.

Hrgovic, I., Doll, M., Kleemann, J., Wang, X. F., Zoeller, N., Pinter, A., Kippenberger, S., Kaufmann, R., \& Meissner, M. (2016). The histone deacetylase inhibitor trichostatin a decreases lymphangiogenesis by inducing apoptosisand cell cycle arrest via p21-dependent pathways. BMC Cancer, 16(1), 763. http://dx.doi.org/10.1186/s12885-0162807-y. PMid:27716272.

Huang, S. P., Levesque, E., Guillemette, C., Yu, C. C., Huang, C. Y., Lin, V. C., Chung, I. C., Chen, L. C., Laverdière, I., Lacombe, L., Fradet, Y., Chang, T. Y., Lee, H. Z., Juang, S. H., \& Bao, B. Y. (2014). Genetic variants in microRNAs and microRNA target sites predict biochemical recurrence after radiacal prostatectomy in localized prostate cancer. International Journal of Cancer, 135(11), 2261-2267. http://dx.doi.org/10.1002/ijc.28904.

Jebbawi, F., Fayyad-Kazan, H., Merimi, M., Lewalle, P., Verougstraete, J. C., Leo, O., Romero, P., Burny, A., Badran, B., Martiat, P., \& Rouas, R. (2014). A microRNA profile of human CD8 (+) regulatory $T$ cells and characterization of the effects of microRNAs on Treg cell-associated genes. Journal of Translational Medicine, 12(1), 218. http://dx.doi.org/10.1186/s12967-014-0218-x. PMid:25090912.

Jemal, A., Bray, F., Center, M. M., Ferlay, J., Ward, E., \& Forman, D. (2011). Global cancer statistics. Cancer Journal for Clinicians, 61(2), 69-90. http://dx.doi.org/10.3322/caac.20107. PMid:21296855.

Kim, C. M., Choi, J. Y., Bhat, E. A., Jeong, J. H., Son, Y. J., Kim, S., \& Park, H. H. (2016). Crystal structure of TRAF1 TRAF domain and its implications in the TRAF1-mediated intracellular signaling pathway. Scientific Reports, 6(1), 25526. http://dx.doi.org/10.1038/ srep25526. PMid:27151821.

Lei, L., Yan, S. Y., Yang, R., Chen, J. Y., Li, Y., Bu, Y., Chang, N., Zhou, Q., Zhu, X., Li, C. Y., \& Xiong, J. W. (2017). Spliceosomal protein eftud2 mutation leads to p53-dependent apoptosis in zebrafish neural progenitors. Nucleic Acids Research, 45(6), 3422-3436. http:// dx.doi.org/10.1093/nar/gkw1043. PMid:27899647.

Lewinska, A., Adamczyk-Grochala, J., Kwasniewicz, E., Deregowska, A., \& Wnuk, M. (2017). Diosmin-induced senescence, apoptosis and autophagy in breast cancer cells of different P53 status and ERK activity. Toxicology Letters, 265, 117-130. http://dx.doi.org/10.1016/j. toxlet.2016.11.018. PMid:27890807.

Li, Y., Urban, A., Midura, D., Simon, H. G., \& Wang, Q. T. (2017). Proteomic characterization of epicardial-myocardial signaling reveals novel regulatory networks including a role for NF- $\kappa \mathrm{B}$ in epicardial EMT. PLoS One, 12(3), e0174563. http://dx.doi.org/10.1371/journal. pone.0174563. PMid:28358917.

Liu, X., Zhang, X., Ma, K., Zhang, R., Hou, P., Sun, B., Yuan, S., Wang, Z., \& Liu, Z. (2016a). Matrine alleviates early brain injury after experimental subarachnoid hemorrhage in rats: possible involvement of PI3K/Akt-mediated NF- $\kappa B$ inhibition and Keap1/Nrf2-dependent HO-1 inductionn. Cellular and Molecular Biology, 62, 38-44.

Liu, Y., Gao, X., Deeb, D., Zhang, Y., Shaw, J., Valeriote, F. A., \& Gautam, S. C. (2016b). Mycotoxin verrucarin A inhibits proliferation and induces apoptosis in prostate cancer cells by inhibiting prosurvival Akt/NF-kB/mTOR signaling. Journal of Experimental Therapeutics \& Oncology, 11(4), 251-260. PMid:27849335.

Shang, D., Han, T., Xu, X., \& Liu, Y. (2015). Decitabine induceds G2/M cell cycle arrest by suppressing P38/NF- $\mathrm{kB}$ signaling in human renal clear cell carcinoma. International Journal of Clinical and Experimental Pathology, 8(9), 11140-11148. PMid:26617834.

Tan, G., Wu, L., Tan, J., Zhang, B., Tai, W. C., Xiong, S., Chen, W., Yang, J., \& Li, H. (2016). MiR-1180 promotes apoptotic resistance to human hepatocellular carcinoma via activation of NF- $\kappa$ B signaling pathway. Scientific Reports, 6(1), 22328. http://dx.doi.org/10.1038/ srep22328. PMid:26928365.

Tokunaga, F., Nishimasu, H., Ishitani, R., Goto, E., Noguchi, T., Mio, K., Kamei, K., Ma, A., Iwai, K., \& Nureki, O. (2012). Specific recognition of linear polyubiquitin by A20 zinc finger 7 is involved in NF- $\kappa \mathrm{B}$ regulation. The EMBO Journal, 31(19), 3856-3870. http://dx.doi. org/10.1038/emboj.2012.241. PMid:23032187.

Tsai, J. H., \& Yang, J. (2013). Epithelial-mesenchymal plasticity in carcinoma metastasis. Genes \& Development, 27(20), 2192-2206. http://dx.doi.org/10.1101/gad.225334.113. PMid:24142872.

Volk, N., \& Shomron, N. (2011). Versatility of microRNA biogenesis. PLoS One, 6(5), e19391. http://dx.doi.org/10.1371/journal.pone.0019391. PMid:21572999. 
Wu, W., Dang, S., Feng, Q., Liang, J., Wang, Y., \& Fan, N. (2017). MicroRNA-542-3p inhibits the grwoth of hepatocellular carcinoma cells by targeting FZD7/Wnt signaling pathway. Biochemical and Biophysical Research Communications, 482(1), 100-105. http://dx.doi. org/10.1016/j.bbrc.2016.10.136. PMid:27815069.

Xu, L., Beckebaum, S., Iacob, S., Wu, G., Kaiser, G. M., Radtke, A., Liu, C., Kabar, I., Schmidt, H. H., Zhang, X., Lu, M., \& Cicinnati, V. R. (2014). Micro RNA-101 inhibits human hepatocellular carcinoma progression through EZH2 downregulation and increased cytostatic drug sensitivity. Journal of Hepatology, 60(3), 590-598. http://dx.doi. org/10.1016/j.jhep.2013.10.028. PMid:24211739.

Yang, Y., Zhang, J., Xia, T., Li, G., Tian, T., Wang, M., Wang, R., Zhao, L., Yang, Y., Lan, K., \& Zhou, W. (2016). MicroRNA-210 promotes cancer angiogenesis by targeting fibroblast growth factor receptor-like 1 in hepatocellular carcinoma. Oncology Reports, 36(5), 2553-2562. http://dx.doi.org/10.3892/or.2016.5129. PMid:27666683.

Yao, D., Dai, C., \& Peng, S. (2011). Mechanism of the mesenchymalepithelial transition and its relationship with metastatic tumor formation. Molecular Cancer Research, 9(12), 1608-1620. http:// dx.doi.org/10.1158/1541-7786.MCR-10-0568. PMid:21840933.

Zhang, W., Tang, Z., Zhu, X., Xia, N., Zhao, Y., Wang, S., Cui, S., \& Wang, C. (2015). TRAF1 knockdown alleviates palmitate-induced insulin resistance in HepG2 cells through NF- $\mathrm{kB}$ pathway. Biochemical and Biophysical Research Communications, 467(3), 527-533. http://dx.doi. org/10.1016/j.bbrc.2015.09.165. PMid:26449452.

Zhang, X., Jiang, P., Shuai, L., Chen, K., Li, Z., Zhang, Y., Jiang, Y., \& Li, X. (2016). miR-589-5p inhibits MAP3K8 and suppresses CD90+ cancer stem cells in hepatocellular carcinoma. Journal of Experimental \& Clinical Cancer Research, 35(1), 176. http://dx.doi.org/10.1186/ s13046-016-0452-6. PMid:27835990.

Zhou, X., Zhu, H. Q., Ma, C. Q., Li, H. G., Liu, F. F., Chang, H., \& Lu, J. (2016). MiR-1180 promoted the proliferation of hepatocellular carcinoma cells by repressing TNIP2 expression. Biomedicine and Pharmacotherapy, 79, 315-320. http://dx.doi.org/10.1016/j. biopha.2016.02.025. PMid:27044843. 